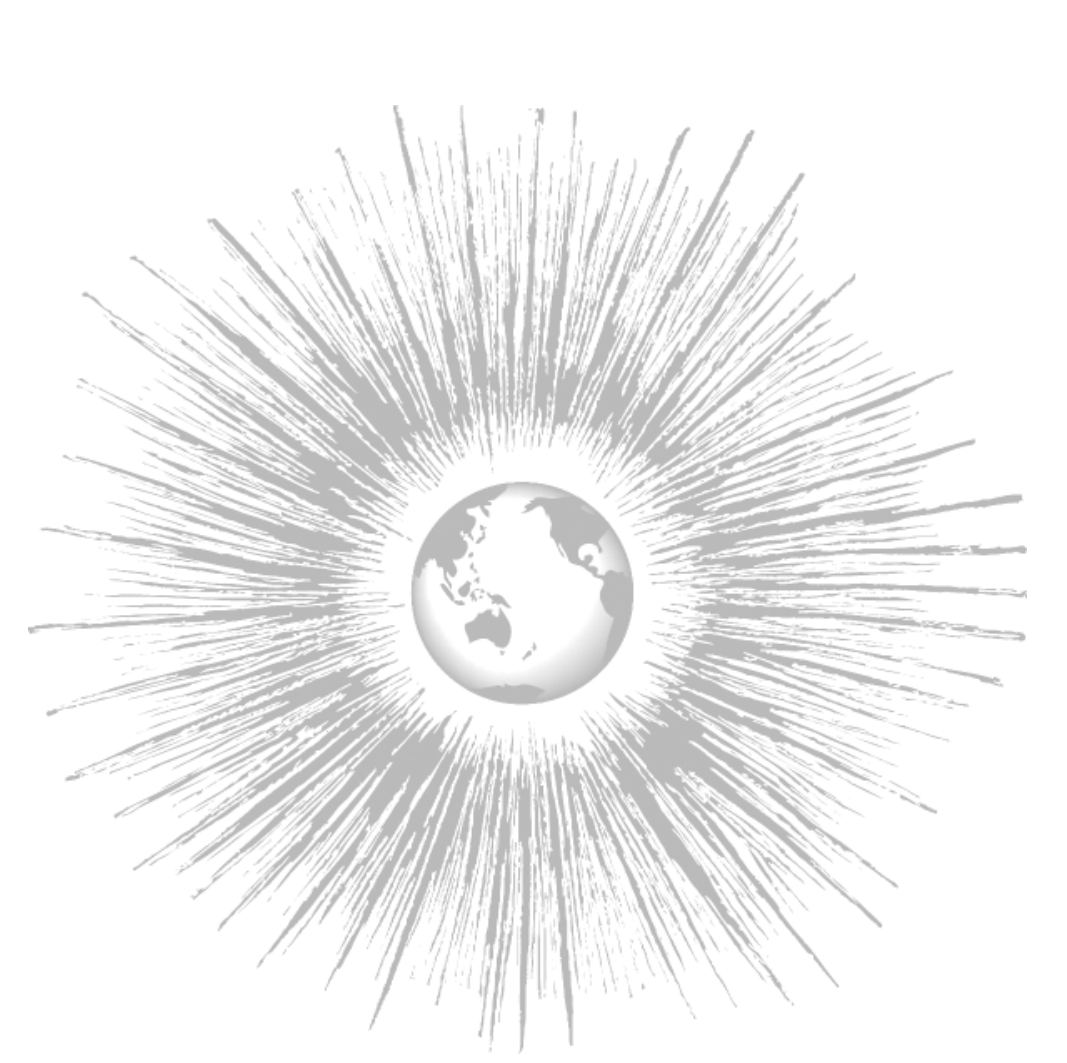

ABSTRACT:

The modern practice of archaeological survey-regional, intensive, diachronic, and interdisciplinary-is well-suited to the study of frontiers. In this paper we provide the exam ple of the Shala Valley Project, which studies the northern Albanian mountain valley of Shala, home to the Shala tribe. Northern Albania is the only place in Europe where tribal societies survived into the $20^{\text {th }}$ century. We attribute their survival to the frontie position of northern Albania, wherein tribal chiefs controlled access to and through valley systems. Shala provides a classic example of a "refuge" society, perched within a strongly contested peripheral zone. The tribe actively and creatively resisted state incorporation during both the Ottoman (Early Modern) and Modern periods. The northern Albanian frontier may have formed much earlier, though, perhaps as early as the Bronze Age. We bring a broad array of evidence to bear on this question, drawn from the ethno-historical, excavation, and of course, survey-archaeological records.

\section{Diachronic Frontiers: Landscape Archaeology in Highland Albania*}

Robert Schon E Michael L. Galaty

\section{INT RODUCTION}

Todern frontier studies began over a century ago with Frederick Jackson 1 Turner's presentation of "The Significance of the Frontier in American History," delivered in I893. In this now iconic paper, Turner not only outlined a general concept of the frontier, but also called attention to the variability of cultural encounters in frontier zones and their bidirectional transformative power. Subsequent scholarship focused more on the former aspect of Turner's thesis: the frontier as "the outer edge of the wave - the meeting point between savagery and civilization," and less on the latter: "the wilderness masters the colonist" (Turner $1920[1893]$ : 34).

More recently, frontier researchers have reoriented their perspective on frontiers from 'edges of advancement,' to 'zones of contact and interaction' (e.g.,
Robert Schon

Department of Classics

University of Arizona

Learning Services Building, Room 216

1512 East First Street

PO Box 210105

Tucson, AZ 85721-0105

rschon@email.arizona.edu
Michael L. Galaty

Department of Sociology and

Anthropology

Millsaps College

1701 North State Street

Jackson, MS 39210

galatml@millsaps.edu
* The Shala Valley Project's 2005 and 2006 field seasons were funded by Millsaps College, the University of Louisville, the American Embassy in Tirana, International Peace Research Association, and two private donors, Bud Robinson and John Stevens. We are very grateful for their support. We would like to acknowledge the contributions to this paper of our SVP colleagues, in particular Ols Lafe, Wayne Lee, Mentor Mustafa, Zamir Tafilica, Charles Watkinson, and Antonia Young. This paper was originally presented at the Annual Meeting of the American Society for Ethnohistory, Santa Fe, New Mexico, November 19, 2005, in a session on frontiers. We would like to thank Tom Hall for inviting us to participate. Finally, we would like to thank Mitch Allen for an insightful and constructive review of a first draft.

JOURNAL OF WORLD-SYSTEMS RESEARCH, XII, 2, DECEMBER 2006, 23I-262 http://www.jwsr.org

ISSN $1076-156 \mathrm{X}$

(C) 2006 Robert Schon \& Michael L. Galaty 
Hall 1986, 1998, 2000, 200I; see also Kardulias (1999), in particular the idea of 'negotiated peripherality'). With this reorientation, and given historical, ethnographic, and archaeological data of finer resolution that allow us to see better what goes on in contact zones, scholarly thinking about how frontiers form and develop has changed. Culture contact is no longer seen as a unidirectional process in which indigenous groups are passive recipients of the cultural norms of expanding empires (Lightfoot and Martinez 1995). Rather, a multitude of case studies illuminate the complexity of interactions that occur in frontier zones and call attention to the transformations that take place on either side of notional boundaries (see examples in Chase-Dunn and Hall 1997; Hall, ed. 2000).

Over the last couple of decades, many archaeologists have adopted this new perspective (e.g., Parker 2006; Stein 1999, 2003; Schortman and Urban 1992; Wells 2005). Culture contact leaves its mark in the material record, and as a result, it is a process that archaeology is well suited to study. As with other disciplines that examine frontiers, model building and finer data resolution highlight the complexity of frontier zones and cause them to evade monolithic definition. While this may seem problematic, we welcome this complexity. In this paper, we focus on one aspect of frontier studies (indigenous responses to imperialism) and one region where culture contact has taken place (northern Albania) in order to demonstrate the utility of investigating frontiers through archaeology.

\section{FRONTIERS AND ARCHAEOLOGICAL SURVEY}

The goal of this paper is to demonstrate how regional survey data can be employed to elucidate aspects of culture contact in frontier zones. We set out to achieve this goal by first briefly presenting the aspects of regional survey in general that can directly inform the study of culture contact. And second, by presenting as a case study the preliminary results of our own fieldwork in highland Albania.

Archaeological survey is an ideal technique with which to study contact zones. In the first place, it is regional in scale-as are frontiers. A survey project can construct its sampling universe to encompass an entire zone where contact occurred, rather than focusing on isolated sites within that broader spatial arena. Secondly, archaeological survey is diachronic. Frontier zones in one period are often frontier zones in other periods as well. The diachronic study of a single region with multiple episodes of culture contact can be highly illuminating. Thirdly, regional survey can be interdisciplinary in approach, including not just archaeologists, but historians, ethnographers, and geo-scientists as well.
Fourth, and finally, surveys collect data about settlement patterns, landscape change, and patterns of land use that pertain to the individuals most affected by frontiers: those who lived in them, so-called 'people without history' to paraphrase Wolf (1997).

In this light, our project, the Shala Valley Project (SVP), ${ }^{1}$ parallels Lightfoot's approach at Fort Ross of a "holistic, diachronic, and broadly comparative" examination of culture contact (Lightfoot 1995: 202). The SVP combines all of these factors in order to study one small frontier zone: it is regional in scope, diachronic and interdisciplinary in approach, and is gathering multiple lines of evidence to demonstrate how people living in a high-mountain valley successfully resisted incorporation by multiple external powers.

\section{THE SHALA VALLEY PROJECT}

Albania is a small country located along the Adriatic coast of the Balkan Peninsula between Greece to the south and the former Yugoslavia to the east and north (Figure I). The northern high mountains are typically described as being extremely remote. For example:

[Northern Albania is] among the wildest and most inaccessible [areas] of the Balkan Peninsula and peopled for the most part by savage and fanatical mountaineers. (Sir Arthur Evans 1885, quoted in Hammond 1976: 35)

The degree to which the mountaineers of northern Albania have or have not been isolated from the outside world is open to question. Our initial research indicates that materials and people moved in and out of the mountains with relative ease. That said, if the people of Shala had wanted to isolate themselves, they certainly had the means to do so; the mountains that surround the valley approach 3000 meters and can be crossed only via a small number of high-altitude passes. The southern entrance to the valley is at a point where the Shala River cuts through the mountains between spectacular cliffs, the "Gates of Shala.' Sealing the valley would have been a relatively easy matter and in fact was done (with tree trunks) in the early $20^{\text {th }}$ century when the Montenegrins invaded Albania and took Shkodër (Durham 1914: 15, 27, 35). Extreme isolation may help to explain the origins and persistence in northern Albania, Shala included, of so-called 'tribal' societies (see Boehm 1983, 1984a, 1984b regarding similar societies in Montenegro). However, we also suspect that their position in a frontier zone might help to explain the formation and preservation of the northern Albanian tribes.

1. See http://www.millsaps.edu/svp. 
Figure 1 - Map of Albania Showing Location of the Shala Valley

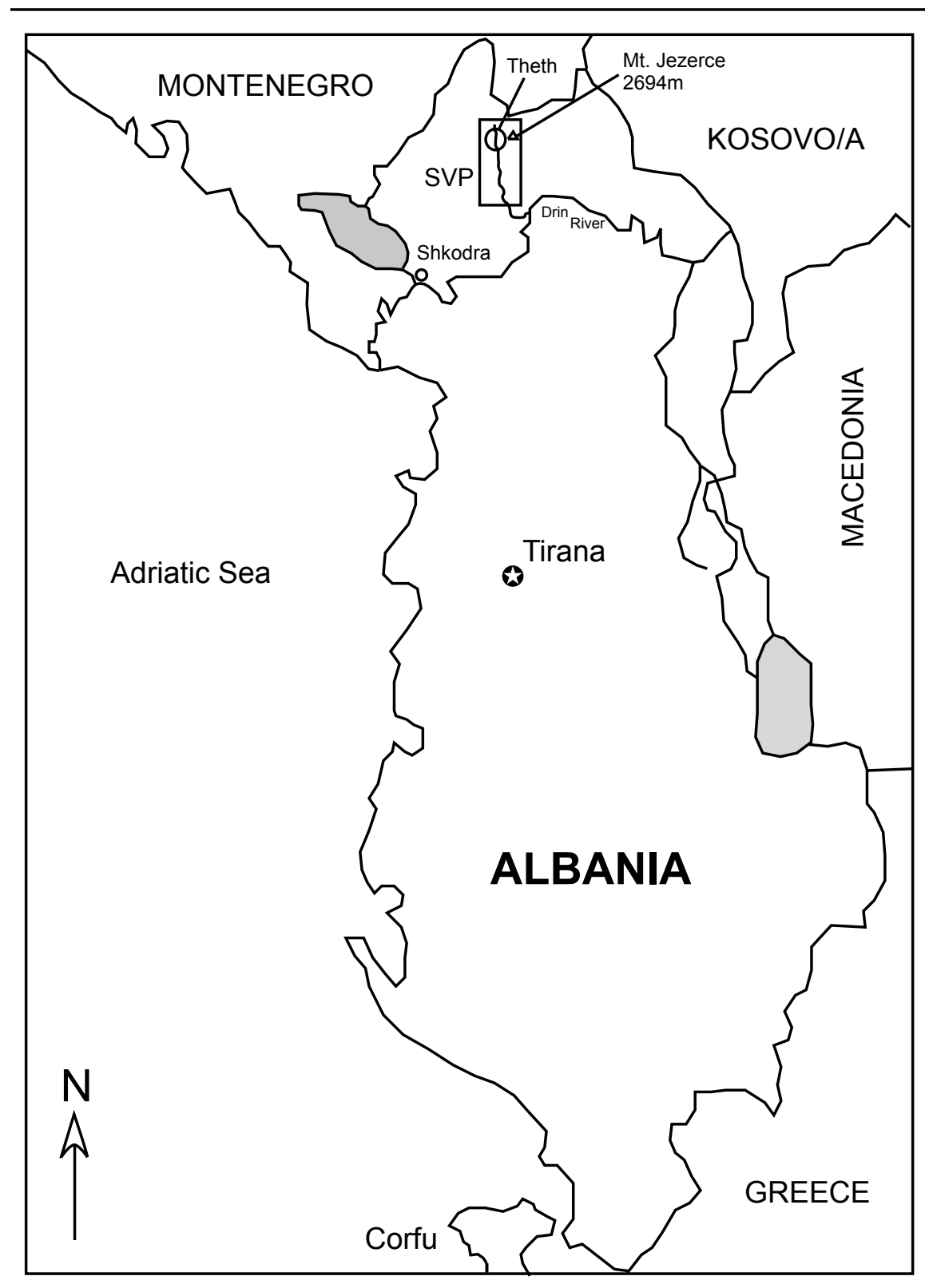

In the Dukagjin region of northern Albania, oral customary laws regarding kinship relations and tribal political organization were codified by a $15^{\text {th }}$ century chief named Lekë Dukagjini. The Kanuni i Lekë Dukagjinit was not transcribed in full until the early $20^{\text {th }}$ century by a Franciscan priest, Father Shtjefën Gjeçov (1989; see also Hasluck 1954). Today, aspects of the tribal system continue to operate in places like Shala, in matters of kinship, such as marriage and inheritance for example (Odile 1989; Whittaker 1968, 1976). Large households (shpia) organized into neighborhoods (meballa) share patrilineal descent from a common apical ancestor thereby forming exogamous segmented clans (fisi). Several neighborhoods and fisi together compose a single village. Political power is vested in the person of the family patriarch (zot $i$ shpi). Family heads are appointed or elected to a village council (kuvend) that makes decisions of importance to the whole community. A single council member is elected 'headman' or kryeplak. In Ottoman times, several villages and fisi might be politically joined in a bajrak (a 'banner') led by a bajraktar (a 'banner chief'). Bajraks formed loose tribal confederations; e.g. those of the Shala 'tribe' joined Shosh, Shala's nearest neighbor to the south, and several other tribes, to form the Dukagjin 'confederacy' (farë), one of ten tribal confederations in northern Albania.

Life in Shala is difficult. The climate is Continental to Alpine and the winters are long and hard. The economy is currently built around sedentary agropastoralism (i.e. 'mixed' village farming; see Halstead 1990) and functions at or just below subsistence levels; government aid or remittances from overseas relatives bridge the gap. Settled agro-pastoralism and tribal socio-political organization together have had a profound effect on Shala's landscape and built environment (Plate I). Large stone houses, some of them fortified ( $k$ ulla, smallwindowed towers that provide protection and sanctuary to wanted men), dot elaborately terraced foothills. Fields are irrigated and run-off is controlled by a complex system of small dams and canals. Property boundaries are marked by stone walls and fences, and deeply entrenched, clearly very old paths link fields and homes.

During the summers of 2005 and 2006, the SVP conducted research in the village of Theth (which is divided into nine neighborhoods), located at the upper end of the Shala Valley, and in lower Shala, in the neighborhoods of Nderlysaj, Gak, Lekaj Musha, Gimaj, and Nen Mavriq (Figures 2 and 3). We intensively surveyed all of the cultivated or cleared land in both areas (circa $4 \mathrm{sq} \mathrm{km}$ in 683 tracts, $15-\mathrm{m}$ walker spacing). Many of the forested areas around neighborhoods were surveyed extensively, as were several of the high-altitude pastures. In Theth, all visible architecture (460 structures) was located and recorded. All structures were mapped and photographed, and many were drawn. At the time of archaeological and/or architectural survey, preliminary interviews were 
Plate 1 - View of the Ulaj, Kolaj, and Grunasi Neighborhoods (mehalla) of Theth Village, Looking South

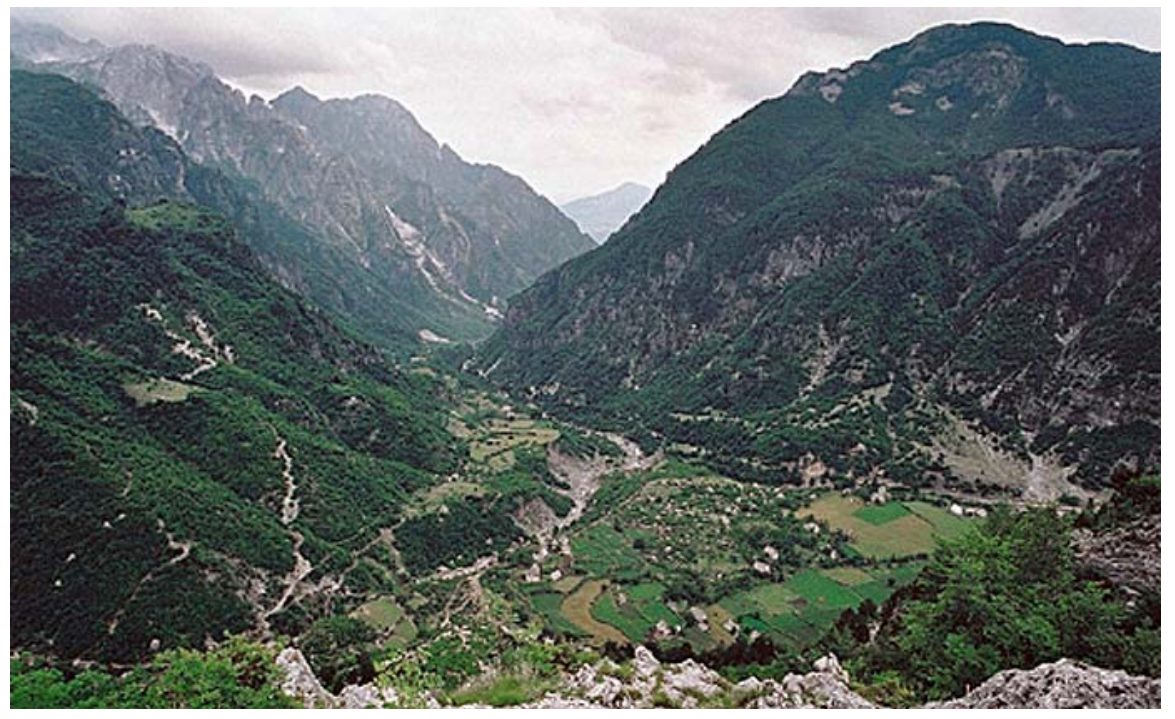

conducted with the land- and/or home owners. Heads of 26 households later participated in much longer, more detailed interviews (composed of questions relating to family and social structure, local history, land use, economy, migration, and change) conducted by the two project ethnographers. The picture of Shala, past and present, that is emerging from our fieldwork is an intriguing one. ${ }^{2}$

\section{RESULTS}

Evidence for prehistoric settlement in the valley is confined to the Middle Paleolithic period (Figure 3; SVP Site ooI) and perhaps to the Bronze and Iron Ages (Figures 2 and 3; SVP Site 006, and perhaps Sites 002, 005, and 008). There are two major historical periods during which we know that our study region was a frontier: the Ottoman period and the period during which the Albanian

2. The architectural survey will recommence in lower Shala in 2007. Ethnographic interviews have taken place primarily in Theth, but will be extended south in 2007. Our goal is to survey archaeologically the whole Shala tribal territory, from the headwaters of the river in Okol to the Gates of Shala. About two-thirds of the territory has been surveyed thus far.
Figure 2 - Map of Tracts and Structures Surveyed by the Shala Valley Project in 2005

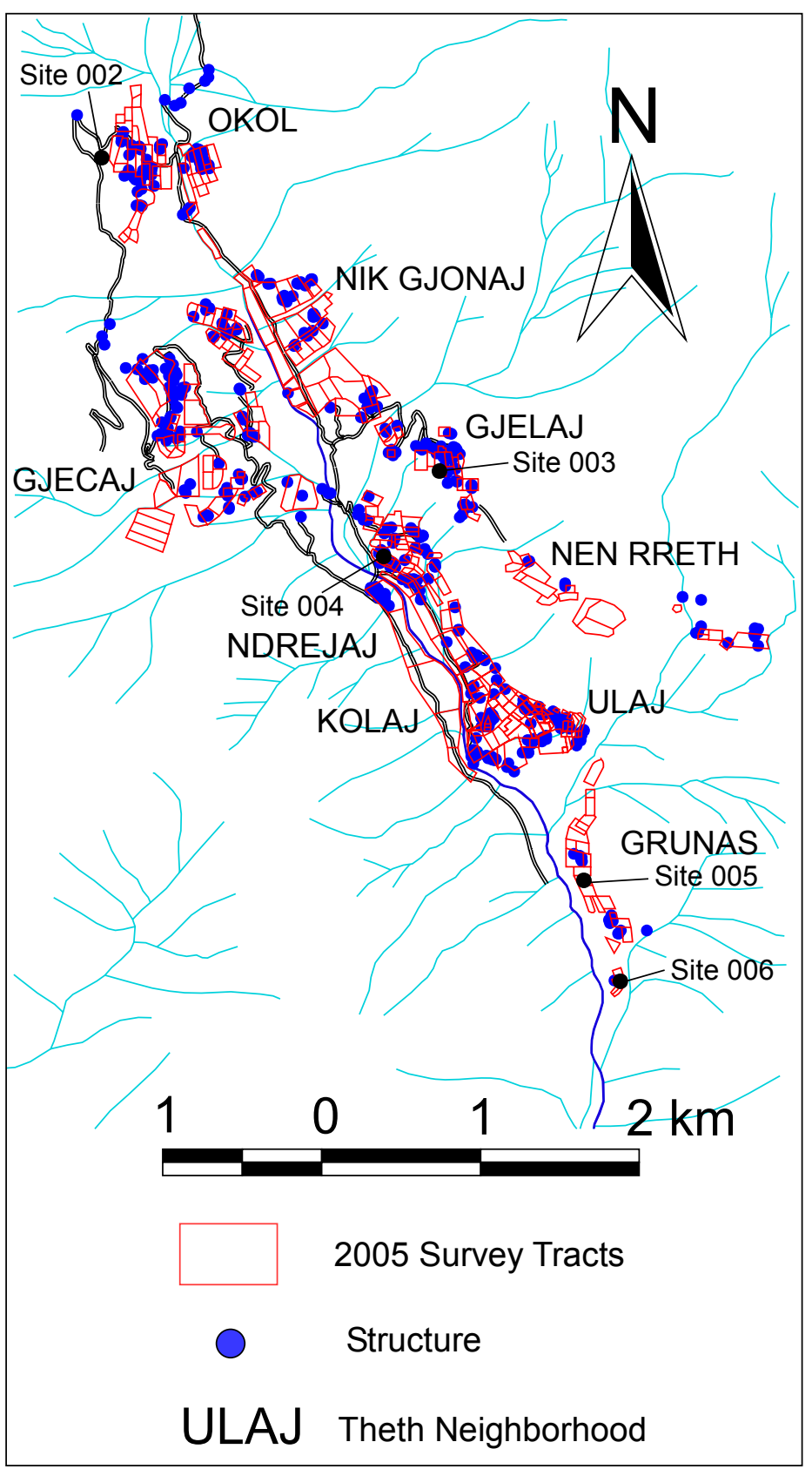


Figure 3 - Map of Tracts and Structures Surveyed by the Shala Valley Project in 2006

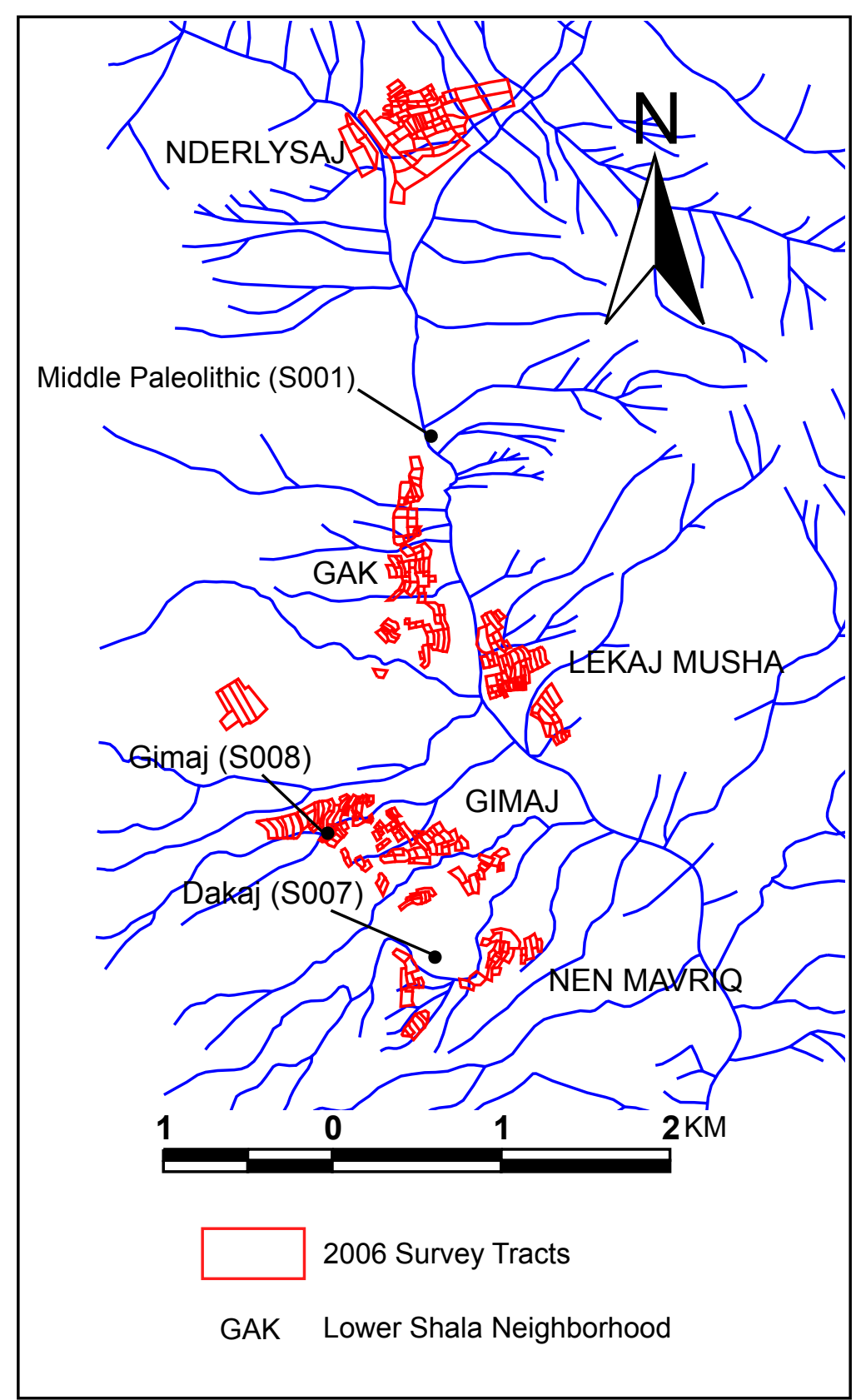

nation state formed (first under King Zog and subsequently under the totalitarian Communist dictatorship of Enver Hoxha). The situation in Shala during the earlier historical periods (e.g., during the Roman and Byzantine periods) is unclear, but it may be that the valley was abandoned during this time, or only used on a temporary, seasonal basis. ${ }^{3}$

In both the Ottoman period and during the early $20^{\text {th }}$ century imperial powers encroached upon the territory of local, tribal groups with the goal of incorporating them into their bureaucratic systems. The relationships between tribes were mitigated by local politics, but also by outside forces. When an external group impinged on their territory, local differences were put aside to react to the greater threat. Thus, the activity of core states within the northern Albanian frontier had strong and lasting effects on the region's socio-political systems.

\section{Prehistoric Shala}

Humans (in this case Homo sapiens neanderthalensis) first entered Shala during the Middle Paleolithic period, probably during the last interglacial (circa I31,000-II4,000 years ago) when the mountains would have been free from permanent ice and snow cover. In 2004 and 2005 we collected stone tools of classic Mousterian type at SVP Site oor (Figure 4). The valley would not have been inhabitable in Upper Paleolithic times, and we have found no evidence for Mesolithic or Neolithic occupation.

At the tail end of the 2005 field season, we identified a small structure at the southernmost tip of the neighborhood of Grunas in Theth (Figure 2, Plates 2 and 3). The architectural survey indicated that the ruined building was unlike any other known structure in Shala. As a result the site (dubbed SVP Site 006) was subjected to test excavations in $2006 .^{4}$

Preliminary results indicate that Site 006, which actually is composed of five different structures and is associated with various terraces and walls, is probably Late Bronze Age and/or Early Iron Age in date (circa Iоoо BC; Figures 5, 6, and 7). In four test units and eleven shovel tests, we found many pieces of dark

3. SVP Sites 003 and 004 are Early Modern scatters of pottery associated with existing and ruined house compounds. SVP Site 007 is the Late Medieval fortress of Dakaj, discussed below. See Figures 3 and 4.

4. A longer report on the excavations at SVP Site 006, with maps and photos of artifacts, is available at the project website:

http://www.millsaps.edu/svp/SVP\%20final\%20report\%202006.pdf 
red, burnished pottery that is similar to prehistoric pottery found elsewhere in northern Albania. At the very top of the cultural horizon we found a few small lumps of iron. Stone tools, including one flake of tan chert that may have been imported, and fragments of bone were found throughout. There also was a substantial amount of charcoal, and we have submitted samples for radiocarbon dating. ${ }^{5}$

One interesting aspect of Site 006 is that it is located in a defensible, stra-
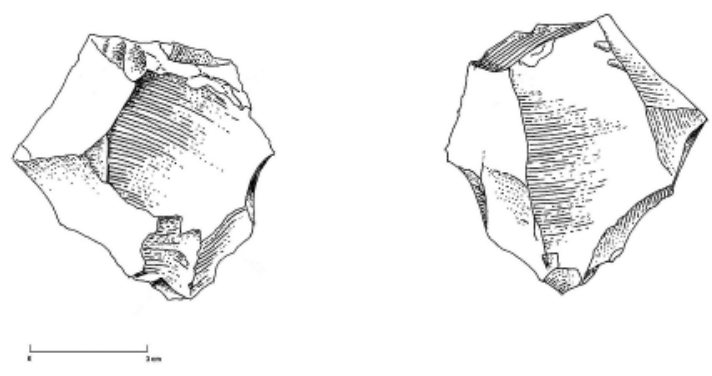
tegic position at a natural choke point in the valley. The site is protected on the west by the Theth River, which passes through a deep gorge at this point, and steep cliffs. To the north of the site is a hill which is spanned by the remains of large, rubble walls. The eastern edge of the site appears to have been fortified (Figures 5 and 6), though we cannot yet be certain that the walls and terraces at the site are prehistoric. ${ }^{6}$ The spur of land upon which the site is situated comes to a point at its southern end, which looks out over the lower part of the valley.

Our working hypothesis is that Site 006 was a late prehistoric stronghold that controlled access to the northern reaches of Shala. It may be that the pastures at Theth were intrinsically valuable and worth controlling. Or it may be that as early as the Bronze Age the Shala Valley constituted an important transportation route for people-shepherds, traders, warriors-moving back and forth between the valley of the Drin River and points north, in Montenegro. ${ }^{7}$ Thus, it is possible that already during the late periods of prehistory and just prior to Roman conquest (the first Roman incursions in northern Albania occurred in $229 \mathrm{BC}$ ), Shala filled a frontier position, perched between competing 'Illyrian' power centers to the south and west along the coast between Shkodër and Dalmatia and to the north and east in interior Montenegro and Kosova. Whatever the case, the valley appears to have been abandoned in Roman and

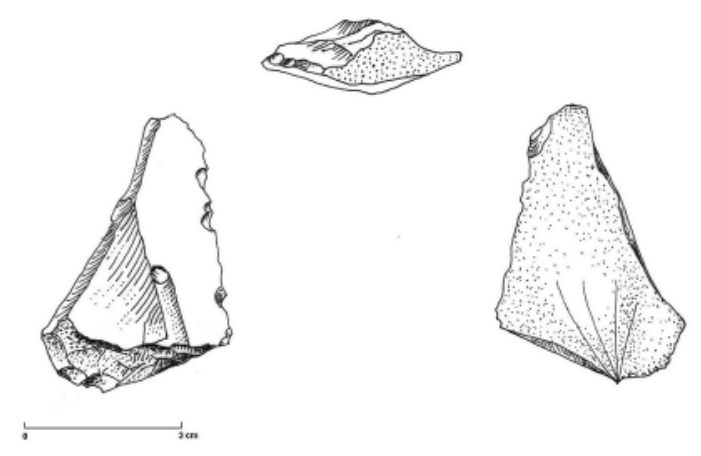

5. The pottery from Site 006 is similar to two pieces of pottery found in 2005 near the rock shelters at Okol in Theth (Site 002). Site 005 is a ring of five large stones embedded into the ground around a central stone. It is near Site 006 and so may be prehistoric. Site 008 is complex of large, overgrown walls located in the neighborhood of Gimaj, possibly prehistoric. Sites 005 and 008 will be shovel-tested in 2007.

6. We plan to study and perhaps date the walls and terraces at Site 006 using various geophysical methods, including magnetic susceptibility and radiocarbon dating. This will take place in 2007

7. The Drin River valley is located to the south of Shala and in ancient times was the main east-west corridor between the Adriatic and the Balkan interior, Kosova in particular (Baçe 1976; Hoxha 2003; Palavestra 1994; Përzhita 200I; Përzhita and Hoxha 2003). 


\section{Plate 2 - Panoramic View of SVP Site 006 from Above and to the East}

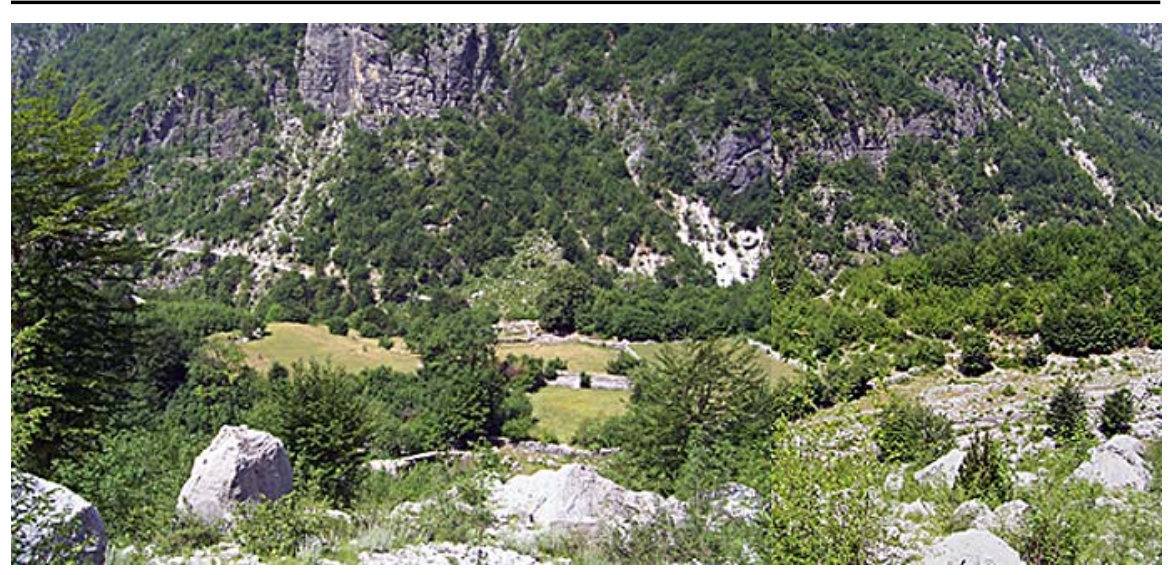

Byzantine times, fully so by the beginning of the Slavic migrations in the $6^{\text {th }}$ century AD.

\section{Ottoman}

According to tradition, the ancestors of Shala's modern occupants arrived in Late Medieval times (sometime before AD 1500), having fled Ottoman persecution elsewhere. As a result, Shala may constitute a so-called 'region of refuge' (Beltran 1979; cf. Boehm 1983, 1984; Hall 2000: 24I). Many of the oldest houses in Shala (some in ruins, many bearing elaborate carvings, a few associated with Late Medieval and Early Modern pottery) mark the valley's first neighborhoods (parts of Gak, Gimaj, and Lekaj in lower Shala, and perhaps slightly later, Okol, lower Gjelaj, and Kolaj/Ulaj in Theth) and architectural survey indicates their gradual expansion as households grew and split.

About the time the first villages were established a fortress was built atop a prominent peak in the neighborhood of Dakaj (Figure 3 and Plate 4). In 2006 we carefully mapped the entire site (SVP Site 007; Figure 8). Our survey produced a large collection of pottery, all of which seems to date to the Late Medieval period (AD I200-I500). Much of the pottery is glazed and decorated, some with incised lines and/or combing, while some is heavily-tempered, coarse cooking ware. We also found ceramic wasters and pieces of iron slag, which may indicate on-site production of pottery and iron tools. Dakaj, it seems, was not simply a fortress or refuge site but it had an industrial function as well.

The site retains some of its circuit walls (Figure 8), but local landowners indicate that wall stones had been carted away to build nearby houses. There are also the remains of at least two, perhaps more, large building complexes.
Figure 5 - Map of the Hinterland of SVP Site 006

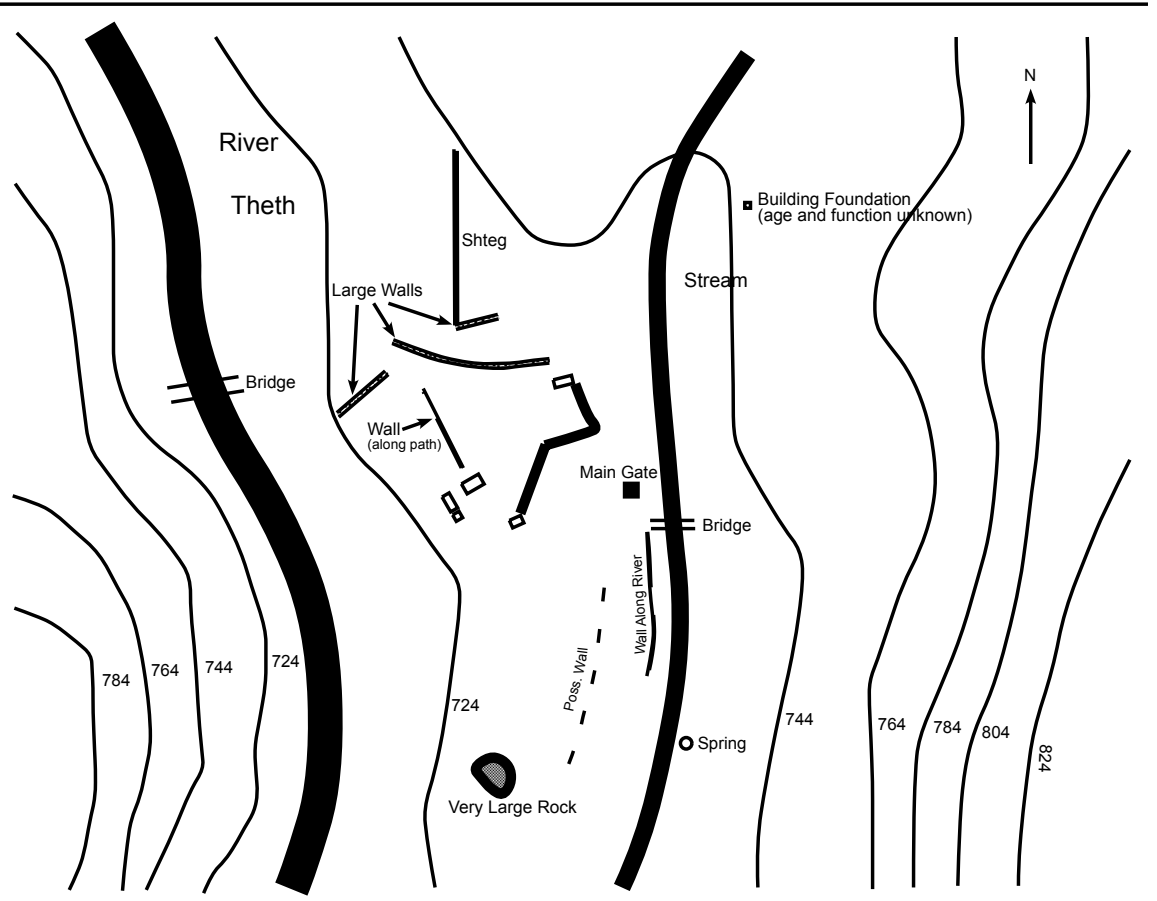

These were likely residential (given the presence of cooking wares and industry), but according to local tradition, a church once existed at Dakaj. Careful surveys of the fields that ring Dakaj (Figure 3) produced no artifacts, so it is not clear whether Medieval houses or a village existed somewhere in the direct vicinity of the site. Certainly the site is well situated for defense and monitoring of the valley. There are excellent views in all directions. It is unclear, however, who controlled Dakaj: local elite, representatives of Venetian interests, or church officials are all possibilities. Continued work at Dakaj, as well as archival research, may help answer this question. In any case, the Late Medieval settlement system is dominated by one large site, Dakaj, repeating a pattern established in the Bronze Age at Grunas. It may be therefore that Dakaj and Grunas served a similar function: control of movement into and through the valley. The ability to isolate and protect the valley took on even greater significance in the coming centuries as the Ottomans put increasing pressure on the northern tribes. Ottoman encroachment triggered several interesting responses on the part of Shala's inhabitants in the areas of economy, land use, and social organization. 
Figure 6 - Map of the Immediate Vicinity of SVP Site 006

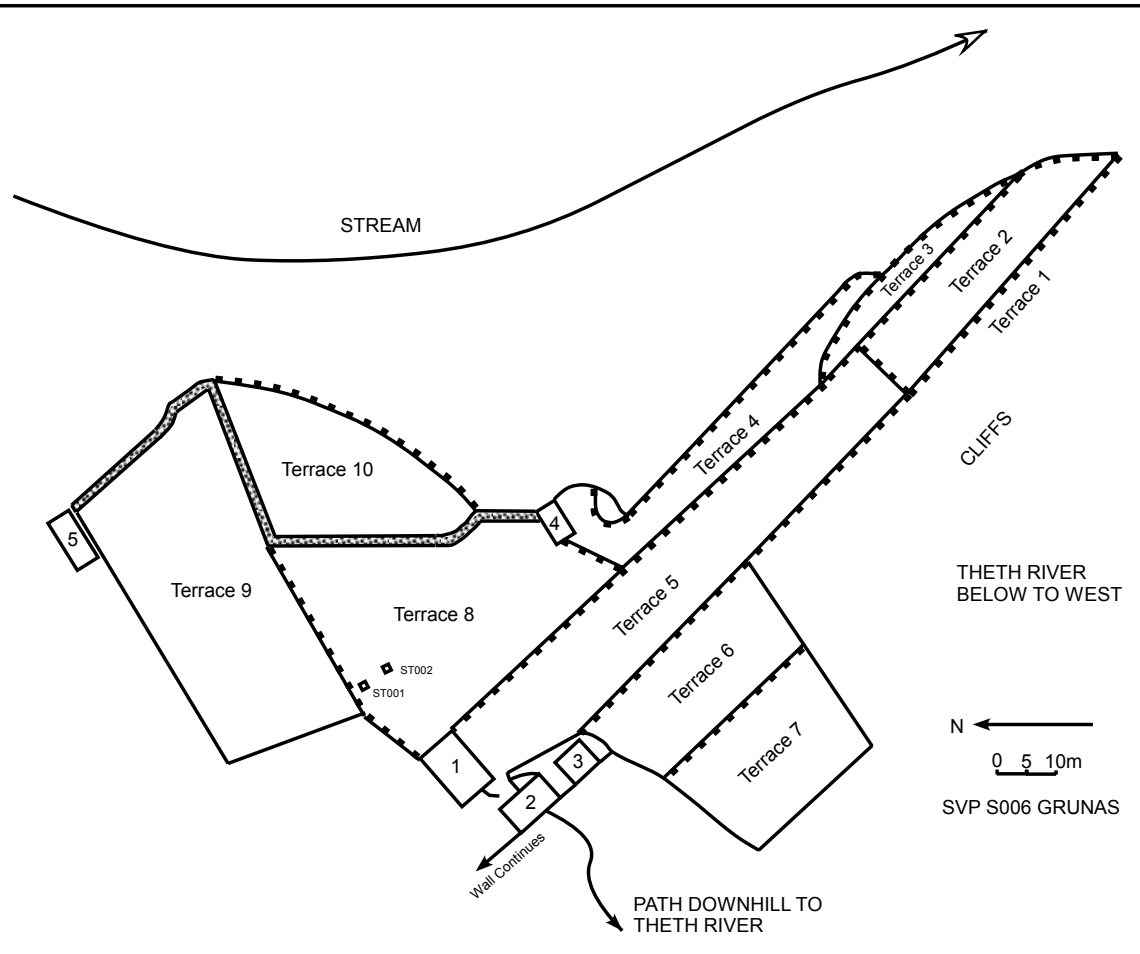

Given northern Albania's geography, climate, and environment, we might predict some form of long-distance, seasonal transhumance of the type that exists, for example, amongst the Koutsovlachs of the high Pindos range of Greece (Chang 1992; Chang and Tourtelotte 1993), but Shala's inhabitants are fully sedentary village farmers. One important question, then, is why yearround village agro-pastoralism developed in Shala in Early Modern times. It may be that Ottoman attempts to incorporate northern Albania and Albanians, through forced conversion to Islam for example (which began in earnest in the $16^{\text {th }}$ century; Pollo and Puto 198I: 90), encouraged a retreat to high valleys, such as Theth. This is the story villagers tell. But flight from Ottoman persecution cannot have been the only factor driving migration to and year-round settlement in northern Albania. Another plausible explanation is that changes in settlement and land use elsewhere in Albania and nearby regions spurred indirectly socio-economic change in Shala.

For example, in the $15^{\text {th }}$ century, the Ottomans extended the timar system (whereby Ottoman soldiers [i.e. sipabis] managed tracts of land for the Sultan) from south and central to north Albania causing population displacements
Figure 7 - Map of Structures 001-003 at SVP Site 006 Showing Location of Excavation Units and Shovel Tests

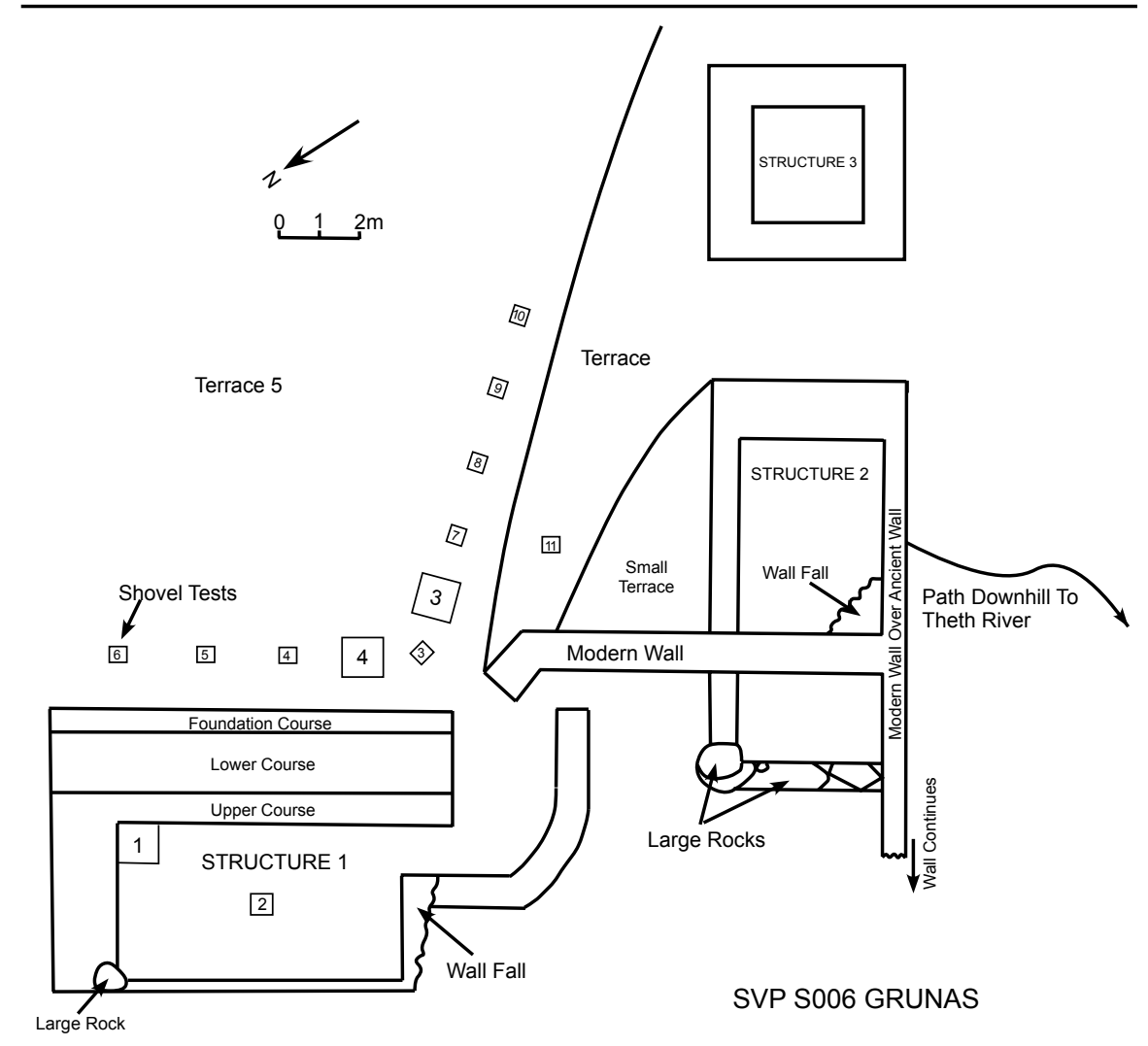

and a change in systems of land tenure (Pollo and Puto 1981: 64, 66, 88-89; Winnifrith 1992). As a result, people may have moved deeper into the mountains not only to escape forced conversion, but also to avoid becoming landless serfs tethered to foreign landlords. With increased immigration, population centers in the mountains may have become larger and access to resources, such as good land, circumscribed. In Theth, as in northern Albania generally, the response was agricultural intensification, perhaps through terracing and irrigation. Investments in the built environment created the landscape visible today. As the landscape became more structured so too did the socio-political system. It was at this time that the tribal system as recorded in the Kanuni $i$ Lekë Dukagjinit probably evolved, a dynamic, social response to the pressures and possibilities of life in a frontier zone.

One major difference between seasonally-transhumant Koutsovlachs and settled, high-altitude Albanian agro-pastoralists is that the Vlachs do not pos- 


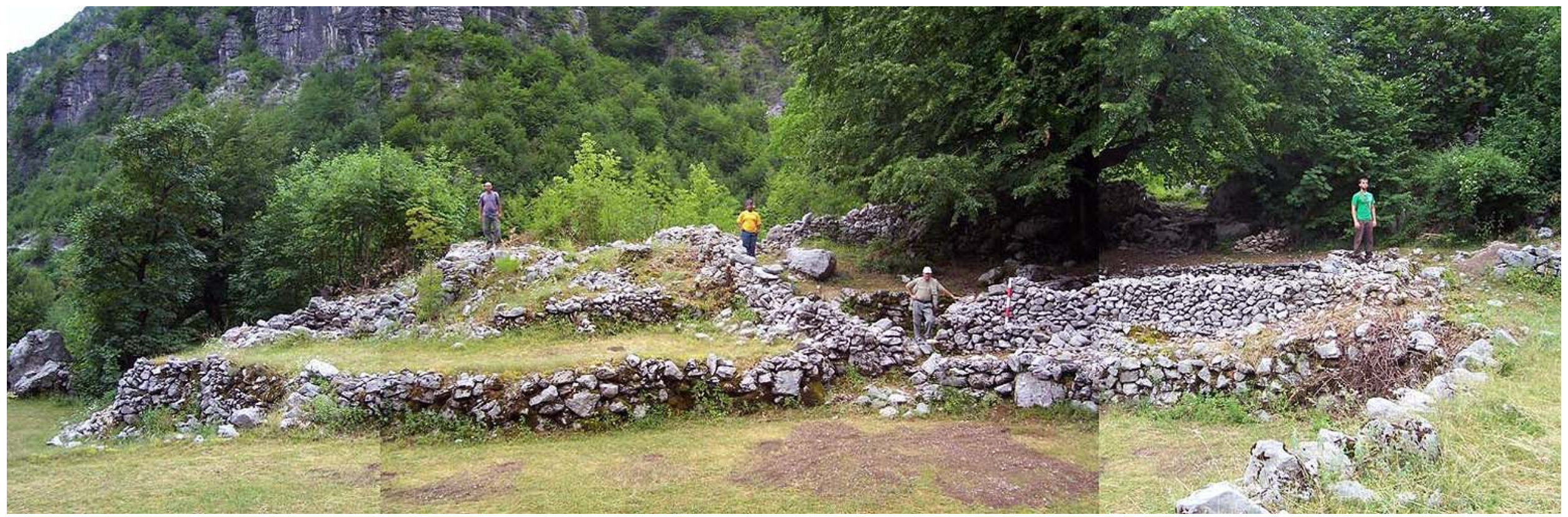

\section{Plate 3 - Panoramic View of Structures 001-003 at SVP Site 006 from the East}

\section{Plate 4 - Dakaj (SVP Site 007) from the North}

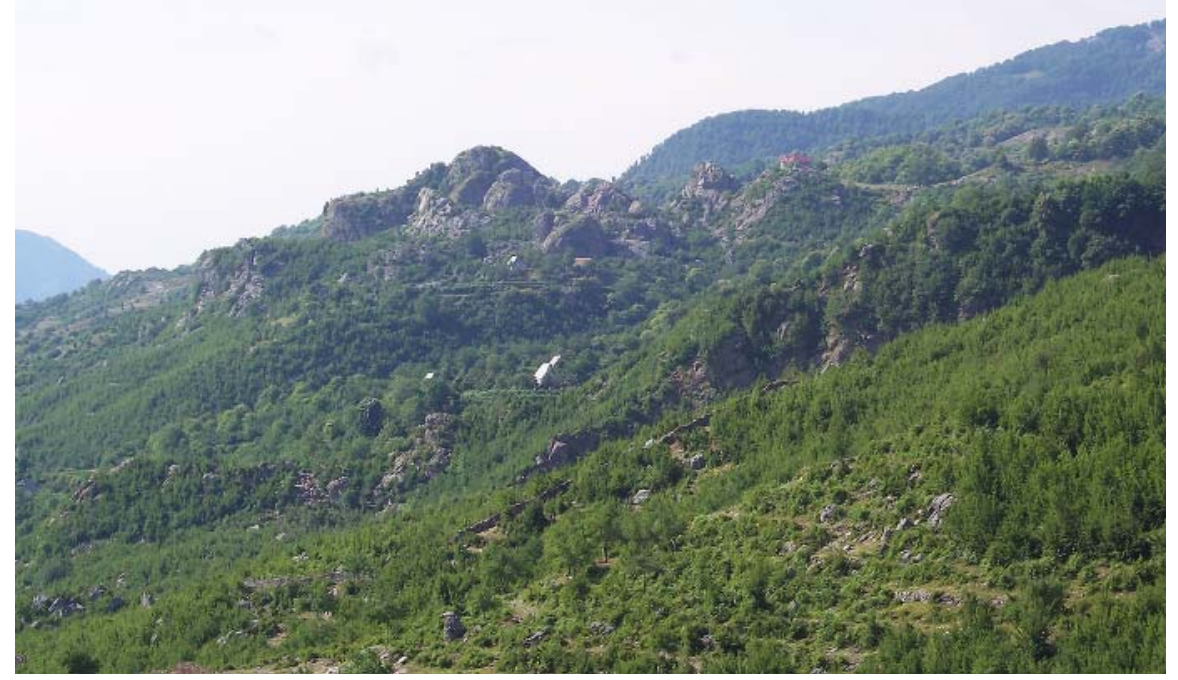

sess tribal political organization (Chang and Tourtollette 1993: 250), whereas the Albanians do. This may be due in part to population pressure and greater resource scarcity in the Dukagjin as compared to the Pindos, requiring a more complex system of land management, but there are equally important historical reasons for the existence and persistence of Albanian tribes. Unlike northern Albania, Vlach kinship relationships and political systems are only very loosely defined. In Ottoman times Vlach herders were well-integrated into the larger regional economy; greater freedom of movement allowed a flexible Vlach economy that responded to risk through regional exchange. Conversely, northern Albanians typically have resisted economic and political integration. In fact, there is good evidence that the Ottomans deliberately discouraged integration by exploiting tribal rivalries. Economic and political competition reduced the possibility of tribal confederation and coordinated, mass uprisings (as had happened under Skanderbeg, the leader of the $15^{\text {th }}$-century Albanian resistance movement). Ottoman officials actually created the bajrak system (in the late $18^{\text {th }}$ century; the first written reference to bajraks is from 1783 ; Ulqini 1991: 167) so that 'banner chiefs' might be played one against the other (Plate 5). In this social atmosphere-population growth and/or movement, shifts to sedentary village agro-pastoralism, scarce resources, increased investment in landscape management, increasingly circumscribed grazing territories, Ottoman political meddling - the kinship and tribal systems were not abandoned, as might have 
Figure 8 - Map of Dakaj

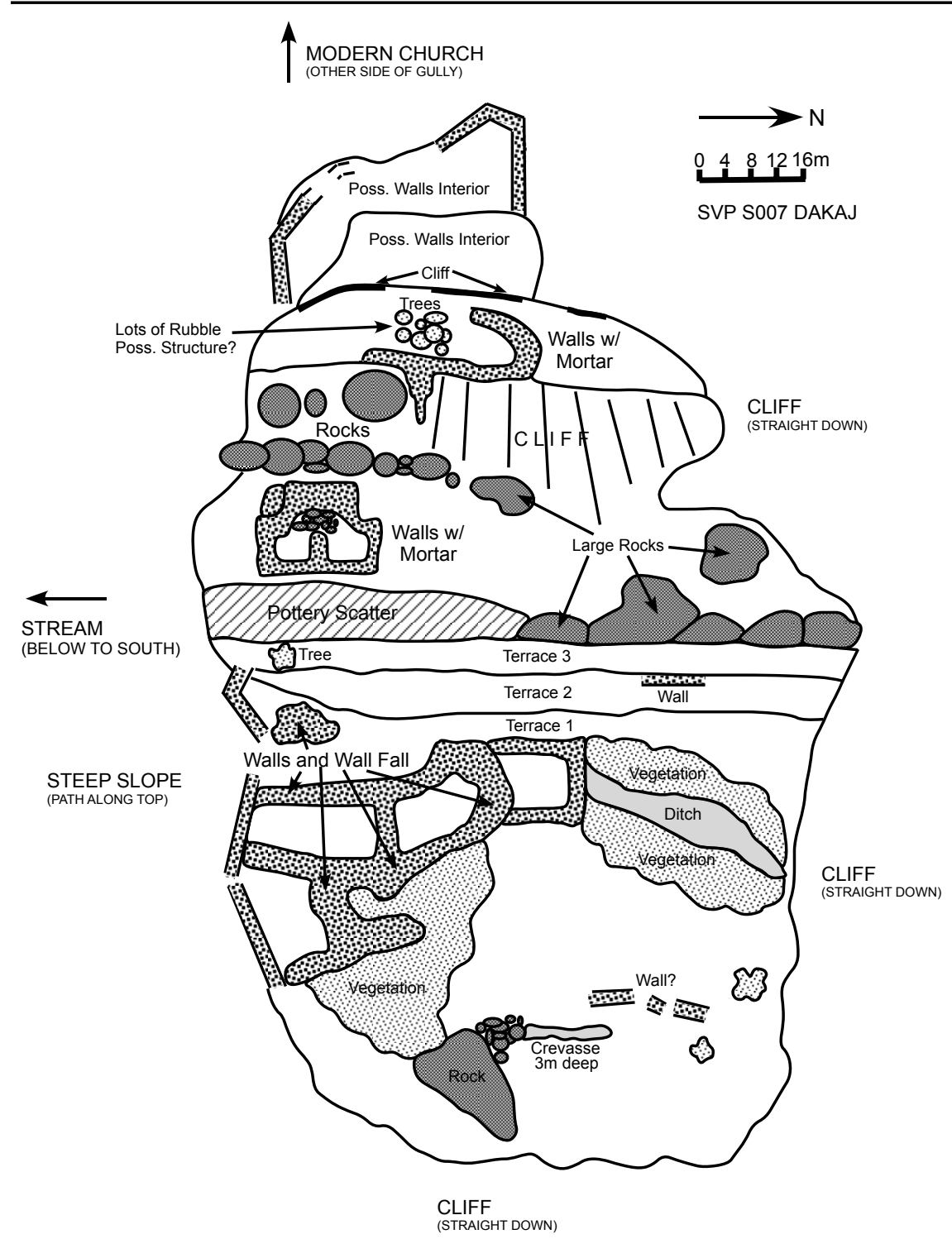

happened with full incorporation into the world-system (Galaty 2002); rather the customary laws that defined social and political relationships were codified in the Kanun, which was then strictly enforced, which is exactly what Hall (2000: 24I) predicts for so-called 'regions of refuge.' It may be that as conflicts between political segments intensified a 'juridical' solution was sought.

\section{Formation of the Nation State}

The northern tribes were a political force in post-independence Albania (Vickers 1999). King Zog (neé Zogu), who ascended to the throne in 1928, was a chief of the powerful Mati tribe. In the interest of regional stability, it was the goal of various western governments to aid in the establishment of a stable Albanian state and the northern Albanian frontier played a key role in the national and international power struggles that accompanied the establishment of a centralized government in Tirana. Tribal politics were primarily local in scale, however tribal leaders were well aware of the ramifications of impending Albanian statehood. As the Tirana Government (as it was called) took form it sought to incorporate the northern highlands into its political and administrative structure. The northern tribes saw the Tirana Government as another external body attempting to impinge on their territory and curtail their traditional lifestyle (Lane 1923). In order to succeed, the central government knew it would have to appease and subdue the country's major social classes: the northern highland tribes (consisting primarily of Catholic and Sunni Muslim pastoralists), the urban Orthodox and Catholic middle class, and the lowland Shiite peasants-remnants of the Ottoman feudal system. In this regard, the perpetually feuding tribes had common interests that fostered political unity. Ultimately some degree of integration was achieved through a combination of negotiation and violence.

In 1921, Rose Wilder Lane, daughter of Laura Ingalls Wilder and someone well familiar with frontiers, visited the Shala Valley of northern Albania with a pair of Red Cross co-workers who hoped to establish a school in the mountains. They were accompanied by Rrok Perolli, an agent of the interior ministry, Rexh Meta, a I2-year-old Muslim orphan (and head of his household) whom Rose eventually put through Cambridge University, and a pair of well-armed gendarmes. In her memoir of the trip, The Peaks of Shala (1923), Lane vividly describes the customs and beliefs of the members of the Shala tribe she encountered and recounts a number of discussions she witnessed concerning the place of tribal society within the nascent nation state.

Throughout her account, the Shala and neighboring Shosh tribes are in the midst of a blood feud. She relates one story in which a Shala man abducted a Shosh woman so that his son might marry her (Lane 1923: 30-3I). Not an unusual event, except the woman turned out to be married and her husband took offense. To preserve his honor, the husband shot and killed the son. According to the Kanun, the murder was unjustified, since it was the father who should have been shot not his son. The result was a series of retribution killings (sanctioned by the law code) that ultimately settled the dispute. Such feuds were 
Plate 5 - 1920s-Era Photograph of the Bajraktar of Theth Symbolically Surrendering His Gun to Representatives of the Tirana Government

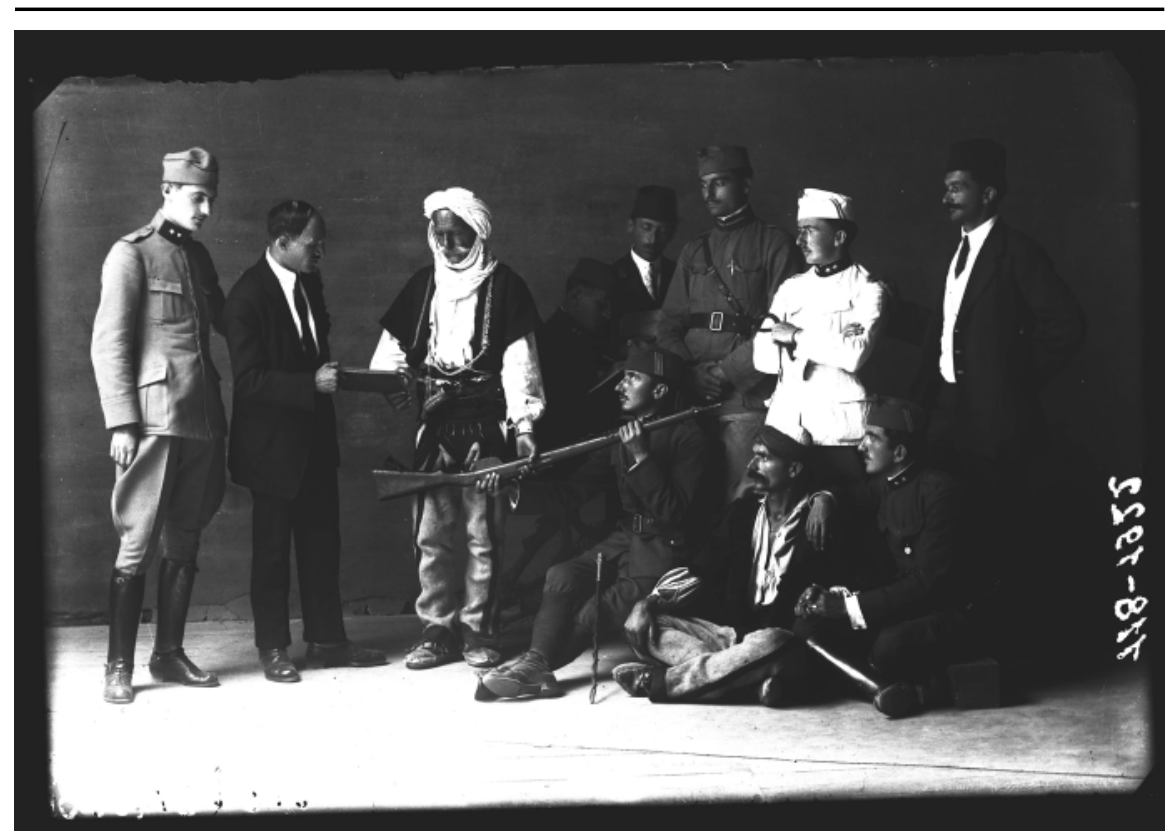

Note: Used with the permission of the Phototekë Marubi in Shkodër, Albania.

endemic to tribal life and leave their material traces in the form of kulla.

Punctuating periods of blood feud are besas, local peace treaties during which all killings cease. A besa may be performed to negotiate an end to a feud, to give men an opportunity to participate in the harvest, or to cope with an outside threat. Such was the case in the mid I92o's.

On December 17, 1924, after a period of exile, former prime minister and future king, Ahmet Zogu, returned to Albania across its northern frontier with well-armed Yugoslavian and Russian troops. A week later he installed himself as dictator in Tirana. Unlike his previous attempts at rule, which included negotiation and appeasement, Zogu treated his rivals with ruthless violence. Among his goals was the disarmament of the mountain tribes-needless to say, not a popular policy. In November 1926, partly funded by the Italian and Yugoslav governments (the very governments that had supported Zogu's return), the northern Gheg tribesmen united and launched a revolt. It was crushed within two weeks. In the ensuing year, men who participated in the revolt were detained and executed.

A plaque, shown to us in Theth by a descendant of Kol Marku (whose name is second on the list), memorializes the men from both the Shala and
Shoshi tribes who participated in the revolt and were executed together in 1927 (Plate 6). Just a few years earlier, these same men would have eagerly killed one another in the midst of the above-mentioned blood feud. The inhabitants of the Shala Valley, while seemingly isolated local actors, living what their contemporaries considered to be an antiquated lifestyle, were nevertheless aware of their role in the global arena. They knew that national-in fact international-laws, such as where to draw borders, would strongly affect them and their families; they had no choice but to declare besa and revolt. This time, though, historical forces were working against them and their traditional defense mechanism, isolation, failed.

The pacification of the northern tribes is strongly reflected in the results of our fieldwork. We have identified a major shift in building style that according to oral testimony dates to the Zogist period. In the late ' 20 s to early ' 30 , houses became significantly less fortified: small windows-frengji-were closed up and/or replaced by large, glass-paned windows; traditional access to secondstory living quarters, by ladder or wood stairs that could be pushed away easily during an attack, was replaced by first-floor doors and internal staircases; animals were moved out of houses and into barns; and most dramatically, large families split up-the need for communal defense no longer existed. Feud was the engine that powered the Kanun. Without feud and the Kanun, and the frontier situation that necessitated them, the tribal system was doomed.

\section{WORLD-SYSTEMS THEORY AND THE NORTHERN ALBANIAN TRIBES}

In the foregoing discussion we have repeatedly (and rather generally) referenced world-systems theory in an attempt to explain the patterns of settlement and settlement change documented thus far in Shala. We have referred to Shala as a 'frontier,' but also as a 'region of refuge.' In light of the results discussed above, it is now possible to describe more precisely a world-systems model for Shala.

Taking a world-systems approach, we might define northern Albania, Shala in particular, as 'marginal,' located within a wide, peripheral frontier zone that stretched across the mid-section of the Balkan peninsula (see Sherratt 1993 for the 'nuclear-margin' concept specifically). The nature of this frontier shifted through time depending on the strength and goals of regional imperial expansion. Various empires touched northern Albania, from several directions, sometimes simultaneously (at which times the region was a 'contested periphery,' see Allen 1997; Chase-Dunn and Hall 1997; Cline 2000) but none it seems managed to fully conquer and/or incorporate the region. It appears to have operated largely outside the interest or control of the imperial politicaleconomies that surrounded it. The question is why northern Albania escaped 
conquest, particularly when so many surrounding regions were 'incorporated' into expanding empires.

Processes of incorporation appear to have operated along a continuum that runs from the complete economic domination of peripheral communities by core states (so-called 'effective' or 'formal' incorporation) to very informal interactions between core states and isolated, independent regions (so-called 'contact' peripheries) (see Hall 1986: 39I-392, 1998: 256, 200I: 242). Most episodes of incorporation appear to fall somewhere in between these two idealized extremes and in reality expanding states used a variety of tactics depending on the situation. 'Regions of refuge' are typically thought to fall somewhere in the middle range, and refuge societies often manage to exploit their marginal, frontier position in order to avoid formal incorporation. Kardulias (1999) refers to this situation as 'negotiated peripherality.'

In late prehistoric times, Shala may have been valuable as prime grazing territory, as a transportation route, or both, and thus worth controlling. We hypothesize that this was the prime function of SVP Site 0o6: to monitor movement through the mid-section of the valley. It may be that those who lived at Site 006 stayed there through the early historical periods, but the valley seems to have been abandoned or at least very lightly used in Roman and Byzantine times. This is quite surprising given the evidence for these periods in regions surrounding Shala, along the Drin River road in particular. Extensive surveys in tribal territories between Shala and the Drin, planned for 2007, may help resolve this mystery. If evidence for early historical settlement is found there, then the negative evidence from Shala will become more meaningful.

Shala appears to have been re-populated on a permanent basis in Medieval times, as documented at the site of Dakaj (SVP Site 007). As described above, Dakaj's role as a fortress is beyond doubt, but it is not yet clear who lived there and whether they dominated the newly established villages or protected them, or both. Local inhabitants of Shala claim that their ancestors arrived as refugees, seeking to escape Ottoman conquest and forced religious conversion elsewhere. We have no reason to doubt these origin stories, but as described above, we believe the foundation and evolution of northern Albania's tribal societies were subject to more complex processes of cause and effect. Shala was isolated, and its inhabitants may have negotiated their peripherality in order to avoid formal incorporation by the Ottoman state, but still they were affected by changes in the outside, imperial world. We have argued, for example, that immigration to the mountains was likely driven also by changes in land tenure on the plains. Increases in population and population pressure were met with an intensification of agricultural production, including terracing and irrigation. It is also no accident that New World crops such as maize, beans, and squash were intro-
Plate 6 - Communist-Era Plaque, Theth, Northern Albania

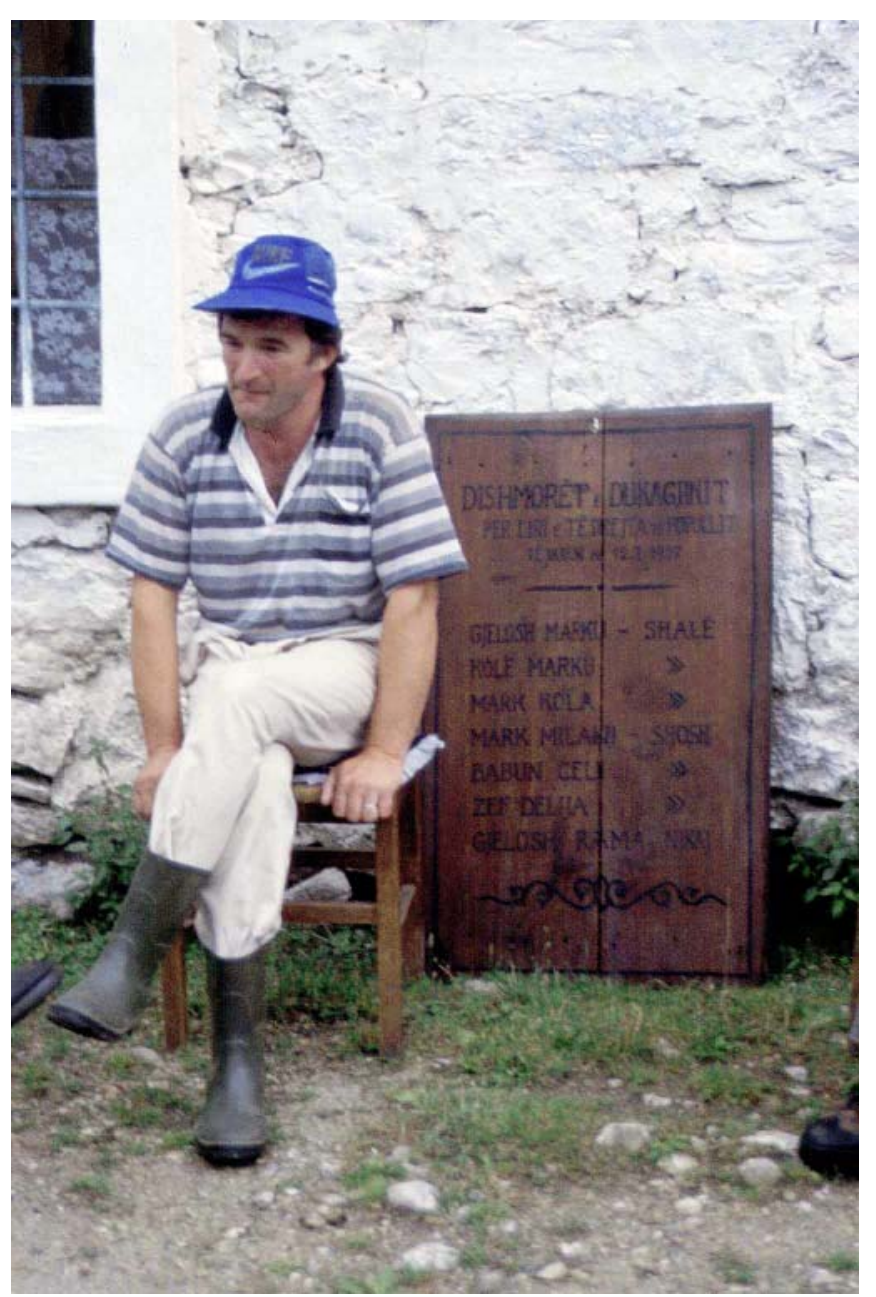

duced to Albania sometime during this period, allowing much larger crop yields (Andrews 1993). Population growth stimulated formation of the tribal system as well as systems of oral customary law and blood feud.

There are several key assumptions in the above sketch that deserve further discussion and are subject to investigation by archaeological survey, as we have defined it. Our model assumes that populations in Shala grew and that population pressure was the result. Beginning with Malthus (I803, I830), most scholars who study mountain eco-systems have asserted that their carrying capacity is rather low and that mountain economies are particularly prone to collapse (e.g. 
McNeill 1992: 2-7). Consequently, many mountain societies carefully regulate marriage, birth, and immigration rates. Emigration from mountain to plain may also serve to relieve population pressure. Whereas these strategies have been well documented for the Medieval-Modern period in the European Alps (e.g., Viazzo 1989), Mediterranean mountain regions have received far less attention (McNeill 1992 is a noteworthy exception).

Most scholars working in the Alps argue further that mountain societies depended on isolation as a means of buffering and limiting population growth (e.g. Netting 198I). Alpine anthropologists applied to the Alpine situation the concept of the 'closed corporate community': small, endogamous villages of small, economically and politically independent nuclear families that closely regulated rules regarding marriage, land tenure, and inheritance. Immigration and emigration were limited. This view of Alpine communities was challenged by Cole and Wolf (1999 [1974]), who argued that in fact, historically most Alpine communities have been 'open' communities, the frontier reserve from which low-altitude urban imperial cores drew surplus people and products. Thus, the real key to understanding mountain demography was not to track the degree to which mountain communities were isolated and isolationist, but rather to understand how the shifting frontier situation affected the movements of individuals in and out of the mountains. Cole and Wolf (1999) therefore view migration as a primary release valve limiting over-population in mountain valleys. Recent scholarship shows that migration was one possible strategy for limiting population in the Alps, but that the migration rate varied through time from village to village (Viazzo 1989).

Mediterranean mountain societies, northern Albania included, differ from the Alps in several important ways. Northern Albanian family structure is dominated by the so-called 'root' or 'complex, joint' family (as opposed to the 'stem' family common in the Alps) (see Gruber and Pichler 2002), in which several generations live together in one large house and share all proceeds of their work (the so-called 'zadruga'; Burns 1976). The land is owned by the patriarch (zot $i$ shpi) and is divided between sons upon his death or retirement. There are no restrictions on marriage and birth and all men are allowed and encouraged to marry and have as many children as possible. Women of the family marry out, and wives are brought in from other, non-related clans. Several of the main population checks employed in the Alps do not exist therefore in northern Albania, and there are two possible means whereby population was controlled: emigration and blood feud.

Blood feud must have had a tremendous effect on northern Albanian populations during some periods. Catholic Church documents indicate that in the period 190I-1905, the male death rate from feud in Shala stood at 26\% (from
Nopsca 1925 cited in Coon 1950: 27; additional statistics in Whitaker 1968: 272274). Feud was also the primary cause for emigration. Men would have fled the mountains not to marry, as was the case in the Alps, but to escape feuds. Thus, we need archaeological means of tracking not just population change, but feuding and emigration as well.

Christopher Boehm (1983, 1984a, 1984b) came to many similar conclusions about the Montenegrin tribal zone, which is in the same mountainous region as the northern Albanian tribal zone. As mentioned above, our application of the 'refuge area' hypothesis to Albania is drawn from Boehm's work. Boehm (1984b: 26) implies that Montenegrin and Albanian tribal systems are similar due to parallel cultural evolution. We find this argument very difficult to accept given that the two cultures are nearly identical in all respects. Rather, we would argue that the two are similar because they share a common ancestral culture; whether Slavic or Albano-Illyrian is unclear. At some point the region was divided along a linguistic/ethnic/religious frontier (the Montenegrins are Orthodox Christian). Given that the Slavic migration began in the $6^{\text {th }}$ century $\mathrm{AD}$, this frontier was perhaps the first to directly affect Shala and may have resulted from efforts on the part of the Orthodox and Catholic churches to control the region, one of the earliest bastions of Christianity in Europe. We might also implicate the Byzantine and Venetian states, though the record of their impact in the tribal zone is less evident than that of the churches.

This 'ethnic frontier' has continued to affect the northern Albanians, Shala in particular, down to the present day. This was especially true after the formation of the Montenegrin state in the early to mid $-19^{\text {th }}$ century. The first thing the $19^{\text {th }}$-century 'vladikas' did when they assumed control of the country was to end blood feuds and raiding, thereby forming a tribal coalition that could effectively resist the Turks (Boehm 1984a: 12-14). ${ }^{8}$ Independence was achieved in 1878 , but by then the tribal system had been completely disassembled. So, state formation in Montenegro happened at the expense of the Montenegrin tribes, and since state formation did not begin in Albania until 1912 (and was not really achieved until 1945 with installation of the Communist dictatorship), the Albanian tribal system survived into the $20^{\text {th }}$ century.

As a consequence of events in Montenegro, in the $19^{\text {th }}$ century northern Albanian tribes found themselves situated firmly between two predatory, enemy

8. The Montenegrin vladikas were paramount chiefs/bishops elected by a council of tribesmen and ecclesiastical leaders; in I850 the position of vladika was secularized and changed to that of an hereditary monarch. 
states, where before there had been only one. The ethnic frontier was transformed into a political frontier, and the Montenegrins became a much more serious threat. The northern Albanian tribes appear to have maintained their independence from the Ottomans over several centuries through a wide variety of strategies (all of which fit nicely the expectations of 'negotiated peripherality' in a 'refuge area'): they occasionally paid token taxes; sometimes agreed to fight alongside Turks, in particular if the enemy was Serb; and revolted when necessary, which typically entailed declaring a general besa. But with Montenegrin state formation and independence, Albanian tribes more often agreed to Ottoman demands, for money, troops, and peace. During this period bajraktars gained power at the expense of local chieftains and councils, throwing the tribal political system into disarray. The result was a spasm of violence (recorded by the Catholic church as a spike in death from feuding; see above), and a general weakening of the tribal defenses, at precisely the time the Albanian nation-state began to form. Thus, by the time of Zog, even truces between sworn enemy tribes, such as Shala and Shosh, could not save the tribal system from its dismemberment at the hands of the Tirana Government. It was the frontier that created the northern Albanian tribesman, and the transformation of the frontier that in the end sealed his fate.

In order to test the above model it is necessary to deploy an archaeological survey methodology that can collect data relating to population, feud, emigration, ethnicity, and religion. Fortunately, our practice of archaeological survey is regional, interdisciplinary (combining traditional archaeological approaches, with ethnography and history), diachronic, and focused on the landscape and land use. Our methods are designed to locate artifacts, but also to identify and record architecture and oral and archival history. In two years of work, we have documented periods of village growth in Shala (primarily changes in the number of houses) that indicate increases in population at key moments of transition, always in response to changes in the frontier context. ${ }^{9}$ There also may have been expansions in the terrace and irrigation systems at times of population growth, though this conclusion awaits scientific testing. We have also identified changes in house architecture (mentioned above) that correspond to decreases in blood feud beginning in the Zogist period. Emigration is much more difficult to view in the material record, but we do have some evidence for extra-valley contacts, particularly in the form of imported, exotic pottery. This at least indicates that Shala was not completely closed to the outside and that products, as well as

9. A detailed description of the timing of these village expansions, written by Wayne Lee, is available in the final report of the SVP's 2005 field season.

http://www.millsaps.edu/svp/SVP\%202005\%20Final\%20Report.pdf. people, moved into and presumably out of the valley, possibly helping to blur ethnic and religious lines.

We also think that the movement of people, whether immigration or emigration, directly affected Shala because the valley served as an attractive, alternative transportation route, in particular for individuals who preferred to remain hidden from imperial eyes, such as raiders, traders, priests, shepherds, and smugglers. This may have begun as early as the Bronze Age and continued into the Medieval period, but was certainly the case during Ottoman and later times. The Shala route was used into recent times by herders and traders heading north to the market at Gusinjë, making Theth somewhat of a crossroads, the place to stop and rest before tackling the Qafe e Pejës, the pass over the mountains. The route north was technically closed after wwi when Gusinjë was awarded to Montenegro, and completely closed after wwir. According to our elderly informants, the closing of the border in 1945 marked the most memorable event of their lives, more memorable even than the beginning or end of Communism.

\section{CONCLUSIONः FRONTIER LIFE AND ARCHAEOLOGY}

While our fieldwork is still in its early stages, a few conclusions may nevertheless be drawn concerning the utility of our approach. Much of the previous narrative relies on ethnohistory, with material remains supplementing and finetuning the picture oral and written sources provide. A pottery scatter, a wood plaque, or a fortified hideout are isolated finds that add color to a preexisting picture, but say little on their own. This may be expected as they all appear within the bounds of living villages - for which oral and written history are preserved.

The strength of archaeological survey, however, lies in its ability to discern patterns in the longue durée (Braudel 1972). To meet this goal we focus on changes in land use and settlement patterns from prehistory to the present over a wide area. As of yet, we have not sampled a sufficiently large universe nor discovered an adequate number of settlements to form concrete inferences concerning long-term patterns of change in these realms. As we expand into adjacent valley systems, we anticipate that meaningful, comparative examples of land use and settlement will emerge. Such patterns will not only complement the image we get from historical sources, but will also add elements about which history is mute. 


\section{LIST OF FIGURES}

Figure I: Map of Albania showing location of the Shala Valley (M. L. Galaty)

Figure 2: Map of tracts and structures surveyed by the Shala Valley Project in 2005 (M. L. Galaty)

Figure 3: Map of tracts surveyed by the Shala Valley Project in 2006 (M. L. Galaty)

\section{Figure 4: Middle Paleolithic stone tools from SVP Site oor (A. Bushati)}

Figure 5: Map of the hinterland of SVP Site 006 (M. L. Galaty and R. Schon)

Figure 6: Map of the immediate vicinity of SVP Site 006 (M. L. Galaty and R. Schon)

Figure 7: Map of structures 00I-003 at SVP Site 006 showing location of excavation units and shovel tests (M. L. Galaty and R. Schon)

Figure 8: Map of Dakaj (M. L. Galaty)

\section{LIST OF PLATES}

Plate I: View of the Ulaj, Kolaj, and Grunasi neighborhoods (mehalla) of Theth village, looking south (A.C. Eek)

Plate 2: Panoramic view of SVP Site 006 from above and to the east (M. L. Galaty)

Plate 3: Panoramic view of structures 00I-003 at SVP Site 006 from the east (M. L. Galaty)

Plate 4: Dakaj (Site 007) from the north (M. L. Galaty)

Plate 5: 1920s-era photograph of the bajraktar of Theth, one Lulash, symbolically surrendering his gun to representatives of the Tirana Government (used with the permission of the Phototekë Marubi in Shkodër, Albania)

Plate 6: Communist-era plaque memorializing the deaths of men who had revolted against Zog's government in 1926 and were executed in 1927. Kol Marku is the second name on the list (M. L. Galaty)

\section{BIBLIOGRAPHY}

Allen, Mitchell J. 1997. Contested Peripheries: Philistia in the Neo-Assyrian WorldSystem. Ph.D. Dissertation, University of California, Los Angeles. Ann Arbor: University Microfilms.

Andrews, Jean. 1993. "Diffusion of Mesoamerican Food Complex to Southeast Europe." Geographical Review 83(2): 194-204.

Baçe, Apollon. 1976. "Fortifikimet e Antikitetit të Vonë në Vendin Tonë [Late Antique Fortifications in Albania]." Monumentet II; 45-74.

Beltran, Gonzalo Aguirre. 1979. Regions of Refuge. The Society for Applied Anthropology Monograph Series, no. I2. Washington D.C.

Boehm, Christopher. 1983. Montenegrin Social Organization and Values: Political Ethnography of a Refuge Area Tribal Adaptation. New York: AMS Press.

- I984a. Blood Revenge: The Anthropology of Feuding in Montenegro and Other Tribal Societies. Lawrence, KS: University Press of Kansas.

. I984b. "Mountain Refuge Area Adaptations." In Cultural Adaptations to Mountain Environments, edited by Patricia D. Beaver and Burton L. Purrington. Athens, GA: The University of Georgia Press.

Braudel, Fernand. 1972. The Mediterranean and Mediterranean World in the Age of Philip II. London: Harper and Row.

Burns, Robert, ed. 1976. The Zadruga: Essays by Philip E. Mosely and Essays in His Honor. London: University of Notre Dame Press

Chang, Claudia. 1992. "Archaeological Landscapes: The Ethnoarchaeology of Pastoral Land Use in the Grevena Province of Greece." In Space, Time, and Archaeological Landscapes, edited by Jacqueline Rossignol and LuAnn Wandsnider. New York: Plenum.

Chang, Claudia, and Perry Tourtellotte. 1993. "Ethnoarchaeological Survey of Pastoral Transhumance Sites in the Grevena Region, Greece." Journal of Field Archaeology 20: 249-264.

Chase-Dunn, Christopher, and Thomas D. Hall. 1997. Rise and Demise: Comparing World Systems. Boulder, CO: Westview.

Cline, Eric H. 2000. '“Contested Peripheries' in World-Systems Theory: Megiddo and the Jezreel Valley as a Test Case." Journal of World-Systems Research 6(I): $8-\mathrm{I} 7$. http://www.jwsr.org

Cole, John, and Eric R. Wolf. 1999. The Hidden Frontier: Ecology and Ethnicity in an Alpine Valley (Second Edition). Berkeley: University of California Press.

Coon, Carelton S. 1950. The Mountain of Giants: A Racial and Cultural Study of the Northern Albanian Mountain Ghegs. Papers of the Peabody Museum of American Archaeology and Ethnology, Harvard University, Vol. 23 No. 3. Cambridge, MA.

Durham, M. Edith. I9I4. The Struggle for Scutari (Turk, Slav, Albanian). London: E. Arnold. 
Galaty, Michael L. 2002. "Modeling the Formation and Evolution of an Illyrian Tribal System: Ethnographic and Archaeological Analogs." In The Archaeology of Tribal Societies, edited by W. Parkinson. International Monographs in Prehistory, Archaeological Series \#15. Ann Arbor, MI.

Gjeçov, Shtjefën. I989. Kanuni i Lekë Dukagjinit [The Code of Lekë Dukagjini]. Translated by Leonard Fox. New York: Gjonlekaj Publishing.

Gruber, Siegfried, and Robert Pichler. 2002. "Household Structures in Albania in the Early $20^{\text {th }}$ Century." The History of the Family 7(3):35I-374.

Hall, Thomas D. 1986. "Incorporation in the World-System: Toward a Critique." American Sociological Review 51:390-402.

. 1998. "The Effects of Incorporation into World Systems on Ethnic Processes: Lessons from the Ancient World for the Modern World." International Political Science Review I9: 25I-267. 2000. "Frontiers, Ethnogenesis, and World-Systems: Rethinking the Theories." In A World-Systems Reader: New Perspectives on Gender, Urbanism, Cultures, Indigenous Peoples, and Ecology, edited by Thomas D. Hall. Lanham, MD: Rowman and Littlefield. . 200I. "Using Comparative Frontiers to Explore World-Systems Analysis in International Relations." International Studies Perspectives 200I(2): 252-268.

Hall, Thomas D., ed. 2000. A World-Systems Reader: New Perspectives on Gender, Urbanism, Cultures, Indigenous Peoples, and Ecology. Lanham, MD: Rowman and Littlefield.

Halstead, Paul. I990. "Present to Past in the Pindhos: Diversification and Specialisation in Mountain Economies." Rivista di Studi Liguri 6I: 6I-80.

Hammond, N. G. L. 1976. Migrations and Invasions in Greece and Adjacent Areas. Park Ridge, NJ: Noyes Press.

Hasluck, Margaret. 1954. The Unwritten Law in Albania, edited by J. H. Hutton. Cambridge: Cambridge University Press.

Hoxha, Gëzim. 2003. Scodra dhe Praevalis në Antikitetin e Vonë [Shkodra and Praevalis in Late Antiquity]. Shkodër: Camaj-Pipa.

Kardulias, P. Nick. I999. "Preface." In World Systems Theory in Practice: Leadership Production, and Exchange, edited by P. Nick Kardulias. Boulder, CO: Rowman and Littlefield.

Lane, Rose Wilder. 1923. The Peaks of Shala. London: Harper-Collins.

Lightfoot, Kent. I995 . "Culture Contact Studies: Redefining the Relationship between Prehistoric and Historical Archaeology." American Antiquity 60: I99-2I7.

Lightfoot, Kent, and Antoinette Martinez. I995. "Frontiers and Boundaries in Archaeological Perspective." Annual Review of Anthropology 24: 47I-492.

Malthus, Thomas. 1803. An Essay on the Principle of Population (Second Edition). London: J. Johnson. Murray.
McNeill, John R. 1992. The Mountains of the Mediterranean World: An Environmental History. Cambridge: Cambridge University Press.

Netting, Robert McC. I98I. Balancing on an Alp: Ecological Change and Continuity in a Swiss Mountain Community. Cambridge: Cambridge University Press.

Nopsca, Franz Baron. 1925. Albanien; Bauten, Trachten und Geräte Nordalbaniens. Berlin and Leipzig.

Odile, Daniel. 1989. "Montagnes Tribales et Coutumiers." L'Ethnographie ro6(2): $43-74$.

Palavestra, Aleksander. 1994. "Prehistoric Trade and a Cultural Model for Princely Tombs in the Central Balkans." In Europe in the First Millennium B.C., edited by K. Kristiansen and J. Jensen. Sheffield Archaeological Monographs 6. J.R. Collis Publications.

Parker, Bradley J. 2006. "Toward an Understanding of Borderland Processes." American Antiquity 7I: 77-Ioo.

Përzhita, Luan. 200I. "Kështjella të Periudhës Antike të Vonë Përgjatë Rrugës Lissus-Naissus [Castles of the Late Antique Period along the Lissus-Naissus Road]." Monumentet 1992-I999: 85-II2.

Përzhita, Luan, and Gëzim Hoxha. 2003. Fortifikime të shekujve IV-VI në Dardaninë Perëndimore [Late Antique Castles of Western Dardania]. Tiranë: Albanian Institute of Archaeology.

Pollo, Stefanaq, and Arben Puto. 198I. The History of Albania: From Its Origins to the Present Day. London: Routledge and Keegan Paul.

Schortman, Edward M., and Patricia A. Urban, eds. 1992. Resources, Power, and Interregional Interaction. New York: Plenum.

Sherratt, Andrew. I993. "Who are you calling peripheral?' Dependence and Independence in European Prehistory." In Trade and Exchange in Prehistoric Europe edited by C. Scarre and F. Healy. Oxford: Oxbow Books.

Stein, Gil. 1999. Re-thinking World-Systems: Diasporas, Colonies, and Interaction in Uruk Mesopotamia. Tucson: University of Arizona Press.

2003. "From Passive Periphery to Active Agents: Emerging Perspectives in the Archaeology of Interregional Interaction." American Antbropologist 104: 903-9I6.

Turner, Frederick Jackson. I920 [I893]. "The Significance of the Frontier in American History." In The Frontier in American History, edited by F. J. Turner. New York: H. Holt and Company.

Ulqini, Kahreman. I99I. Bajraku ne Organization e Vjeter Shoqeror: Fund i Shek. XVII deri me 1912 [The Bajrak in the Old Organization: From the $I 7^{\text {th }}$ Century to I9I2]. Tiranë.

Viazzo, Pier Paolo. 1989. Upland Communities: Environment, Population and Social Structure in the Alps since the Sixteenth Century. Cambridge: Cambridge University Press.

Vickers, Miranda. 1999. The Albanians: A Modern History. London: I. B. Tauris. Wells, Peter S. 2005. "Creating an Imperial Frontier: Archaeology of the Formation of Rome's Danube Borderland." Journal of Archaeological Research I3: 49-88. 
Whitaker, Ian. 1968. "Tribal Structure and National Politics in Albania, 1910-I950." In History and Social Anthropology, edited by I. Lewis. London: Tavistock Publications.

$$
\text { . I976. "Familial Roles in the Extended Patrilineal Kin-Group in }
$$

Northern Albania." In Mediterranean Family Structures, edited by J. Peristiany. Cambridge: Cambridge University Press.

Winnifrith, Tom. 1992. Albania and the Ottoman Empire. In Perspectives on Albania, edited by T. Winnifrith. London: Palgrave McMillan.

Wolf, Eric R. 1997. Europe and the People Without History. Berkeley: University of California Press. 